\title{
Standardization of Trading Board Lot: Effect on Price and Liquidity
}

Nor Elliany Hawa Ibrahim

Universiti Utara Malaysia, Malaysia

Kamarun Nisham Taufil Mohd

Universiti Utara Malaysia, Malaysia

Karren Lee-Hwei Khaw

University of Malaya, Malaysia

*Corresponding author: elliany.hawa@gmail.com

A R T I C L E I N F O

Article history:

Received 21 December 2018

Revised 25 January 2019

Accepted 4 Febuary 2019

Keywords:

Minimum trading unit, Market microstructure, Event study,

Liquidity, Regulation

JEL Code: G10, G12, G14, G18
A B S T R A C T

In this study we examined the announcement and implementation effect of the standardization of trading board lot event at the Kuala Lumpur Stock Exchange, which saw a reduction of the minimum trading unit from 1000 or 200 units to 100 units. The event was implemented in three stages, which affected all listed firms. Our findings showed that there were positive cumulative abnormal returns surrounding implementation days, indicating positive market reception of the new policy. The Securities Commission of Malaysia stated that the trading activities had increased significantly after implementation of the standard trading board lot. Regardless, this claim has never been verified from an academic perspective, which spurred us to compare its effects on liquidity in the pre- and post-standardization period. Our univariate tests showed that as a whole, the lot size reduction improved bid-ask spread and trading activities of stocks in Malaysia. 


\section{Introduction}

Trading board lot, also known as minimum trading unit (MTU), is defined as the minimum number of shares required for investors to submit their trading order. Stock exchanges all over the world adopt different practices in determining their standard board lot size. For instance, the standard board lot size of the NASDAQ Stock Market (NASDAQ) and the Australian Securities Exchange (ASX) is one unit. Meanwhile, the board lot of the New York Stock Exchange (NYSE), the Shanghai Stock Exchange (SSE) and the Shenzhen Stock Exchange (SZSE) is uniformly traded in 100 units per lot. The Tokyo Stock Exchange (TSE) implements various board lot sizes starting from a minimum of one unit per lot to a maximum of 3000 units per lot. The Hong Kong Stock Exchange (HKEX) on the other hand, does not standardize its board lot size as each listed firm decides its own trading board lot size.

The standardization of trading board lot (STBL) is an event to standardize the size of MTU of all listed stocks. Prior to the standardization, only 18 stocks were traded in a board lot of 100 units in Malaysia, and all of them were listed on the MESDAQ (Malaysian Exchange for Securities Dealing and Automated Quotation) market. ${ }^{1}$ By the end of May 2003, all listed stocks on the Kuala Lumpur Stock Exchange (KLSE) currently known as Bursa Malaysia, had to be traded in a multiple of 100 units per lot, which was implemented in three stages, and affected 1,112 listed stocks across the exchange.

STBL is part of the Securities Commission Malaysia's (SC) strategic initiatives outlined in the Capital Market Masterplan, which aims to foster a liquid and efficient market for secondary trading through continuous enhancement of trading processes and market microstructure, to facilitate greater efficiency and liquidity (Securities Commission, 2001). Mathematically, the cost of holding a board lot after standardization would be reduced equivalent to a 2-for-1 (and 10-for-1 ( stock split. The reduction in MTU in many ways resembles stock split (Ahn, Cai, Hamao, \& Melvin, 2014). Therefore, the standardization of MTU is perceived as a national scale stock split that affected more than 98 percent of stocks listed on the KLSE at that time. This study aims to examine the market reaction towards the standardization of trading board lot, in a pure order-driven emerging stock market.

In general, previous studies found significant positive abnormal returns following stock split events and such evidence have been reported to be consistent across different markets (Aydogan \& Muradoglu, 1998; Bechmann \& Raaballe, 2007; Elfakhani \& Lung, 2003; Fama, French, Jensen, \& Roll, 1969; Grinblatt, Masulis, \& Titman, 1984; Lamoureux \& Poon, 1987; McNichols \& Dravid, 1990; Woolridge, 1983). On the other hand, stock split has been found to lead to a reduction in liquidity (Lamoureux \& Poon, 1987; Conroy, Harris, \& 
Benet, 1990; Gray, Smith, \& Whaley, 2003; Huang, Liano, \& Pan, 2015). The lower liquidity level in the post-split period is potentially due to an increase in the cost of market makers that is transferred to investors, or that the market makers used stock split as a mean to increase excess profits (Gray et al., 2003).

Regardless, we have found that there are significant negative abnormal returns surrounding the announcement day. The contradicting evidence can be explained by the strong negative market sentiment surrounding the time of the announcement, due to uncertainties concerning the possibility of a U.S.-led war against Iraq (KLSE, 2003). On the other hand, we have found positive event day abnormal returns during the implementation stages, which signalled positive market reception towards the smaller lot size.

In addition, the KLSE (2003) reported a significant increase in trading activity following the full implementation of the smaller board lot size. Based on the premise that the standardization was a nationwide stock split event, this claim has contradicted scholarly findings. Therefore, there is a need to examine whether STBL has managed to make the stock market more liquid, as viewed and tested from the academic perspective. Hence, we have investigated the effect of implementing the new policy by comparing the level of pre-STBL bid-ask spread, illiquidity and trading activity with post-STBL. Our findings have shown that there is significant improvement in two out of three liquidity measures tested and found evidence consistent with the claim made by the KLSE (2003).

The rest of this article proceeds as follows. The next section presents a review of the literature followed by an outline of the research design and data in the third section. The fourth section discusses the empirical results while the fifth section provides the conclusion.

\section{Literature Review}

The literature on MTU is scarce. Only a limited number of studies directly investigated the effect of lot size reduction or changes on return and/or liquidity (Ahn, 2014; Ahn, et al., 2014; Amihud, Mendelson, \& Uno, 1999; Gozluklu, Perotti, Rindi, \& Fredella, 2015; Hauser \& Lauterbach, 2003; Isaka, 2014; Isaka \& Yoshikawa, 2013). To the best of the researchers' knowledge, only the aforementioned studies are most relevant to be cited as references, which are clearly insufficient. Therefore, we referred to existing studies on stock splits, as economically, it shares the same foundation as standardization. Both, the STBL and stock split reduced the outlays needed to acquire shares and lowered minimum transaction size (Ahn, et al., 2014; Gozluklu et al., 2015). The following sections discuss the two main theories: signalling theory and liquidity theory which are commonly cited to explain standardization and stock split events. 


\subsection{Signalling Theory}

Signalling theory is based on the idea that the information that a party can access may be different from another party. For example, the managers of a firm (insiders) may have more information than investors (outsiders). Even if everyone has the same information, the way the information is interpreted and perceived could be different. Therefore, the assumption that information is consistently and fairly distributed to all parties is arguably unrealistic (Vernimmen, Quiry, Dallocchio, Fur, \& Salvi, 2009).

Theoretical discussions on the signalling theory should begin with the "lemon" argument by Akerlof (1970), who suggested that information asymmetry may exist between a buyer and a seller, and when it does, a transaction may not happen. To initiate a trading, the seller should lower the price that he is willing to sell, and the buyer should increase the price that he is willing to buy, until they reach an equilibrium point where both parties agree to transact. In this situation, both parties have to bear additional costs due to the asymmetric information.

A stock split announcement is commonly interpreted as a positive signal, and therefore, would attract new investors to the firm. Since the signal can be picked up by anyone, such an announcement is expected to increase the number of institutional and individual shareholders (Mukherji, Kim, \& Walker, 1997). The action of splitting cannot be mimicked by other firms as investors will find out later that they are not undervalued (Grinblatt et al., 1984).

Fama et al. (1969) in their seminal article examined evidence on the price behaviour of stock splits and large stock dividends in the months surrounding these events. The findings suggested that stock splits signalled a dividend hike and optimistic earnings prospect for firms. Using monthly price data, they found that stock splits led to positive price reactions provided that the split information was new and unanticipated. The market was efficient because prices adjusted rapidly to new information. In accordance with Fama et al. (1969), many researchers also examined the impact of stock splits on prices in different markets. The results of their studies were consistent with Fama et al. (1969), and thus supported the notion that stock prices reacted positively to stock split announcements (Bechmann \& Raaballe, 2007; Grinblatt et al., 1984; Lamoureux \& Poon, 1987; Lyroudi \& Dasilas, 2006; McNichols \& Dravid, 1990).

In addition, Grinblatt et al. (1984) proposed the attention getting hypothesis to complement the signalling theory. They argued that stock splits could reduce information asymmetry by gaining market interest in firms. Individual investors tended to enter into a long position on stocks that they did not own if they received news that attracted their attention. To take advantage of these situations, firms can use stock splits to increase trading activities on their stocks, 
especially from retail investors (Barber \& Odean, 2008). The attention getting hypothesis acts as an alternative formulation to the signalling hypothesis in explaining positive market reaction surrounding stock split announcements. This hypothesis was also applicable to the standardization event, in which regulators utilized the standardization event to attract more investors to participate in the market (KLSE, 2003). In summary, the majority of studies conducted on the effect of stock splits and/or stock dividend events concurred with the signalling hypothesis that these events had a significant positive effect on firm price.

However, there were studies that reported contradicting findings. Nayak and Prabhala (2001), Huang et al. (2006), and Pavabutr and Sirodom (2010) found that stock split was not a credible signal to predict future dividends and earnings of firms. Nayak and Prabhala (2001) argued that the positive market reaction surrounding a split event was due to the dividend information contained in the split announcement, and not because of the split itself. Huang et al. (2006) found weak evidence between stock split and the future profitability of firms. Similarly, Pavabutr and Sirodom (2010) found insignificant evidence that a split announcement was used to signal future earnings performance. Although inconsistent results were reported, in general the majority of the studies agreed with the signalling hypothesis, where stock splits and/or stock dividends had significant positive effects on the stock price of firms.

In the context of STBL, empirical studies reported significant positive abnormal returns around announcement dates and ex-dates (Desai \& Jain, 1997; Eng, Ha, \& Nabar, 2014; Fama et al., 1969; Huang et al., 2015; Ikenberry, Rankine, \& Stice, 1996). Economically, the standardization of MTU should not affect firm value, as it was similar to a stock split event, in which both were purely cosmetic operations that increased a firm's number of shares outstanding, without affecting its total value (Adaoglu \& Lasfer, 2011). Thus, no abnormal return(s) should be recorded.

With reference to the signalling theory, the motivation to split stocks was due to managers' intentions to reveal their private positive information to the public as they believed that their performance would be better in the future (Brennan \& Copeland, 1988; Brennan \& Hughes, 1991; Grinblatt et al., 1984; Ikenberry et al., 1996). For the STBL, it was expected that this event should have no signalling effect since it was a mandatory event imposed by regulators. Nevertheless, the STBL might have information content if the present board lot size of either 200 or 1000 was too expensive for retail investors. In this case, the market in aggregate should show a significant improvement following the announcement of lot size reduction. Thus, the hypothesis for this study is as follows:

$\mathrm{H}_{1}$ : Abnormal returns are significantly affected by STBL events. 


\subsection{Liquidity Theory}

In general, liquidity is a term that is hard to define. The definition depends on which aspect of liquidity a researcher intends to examine, and thus many proxies are used for liquidity (Acharya \& Pedersen, 2005). Amihud (2002, p. 33) stated that "...Liquidity is an elusive concept. It is not observed directly but rather has a number of aspects that cannot be captured in a single measure..." O'Hara (1995) defined liquidity as the ability to trade a stock quickly with a small cost. The price behaviour and market viability depend on the trading desires of sellers and buyers. According to Sundaresan and Wang (2009), liquidity is defined as 'ready to access to fund' where investors can easily transact large amounts of stock at minimal cost without adverse price reaction.

Copeland (1979) discussed "optimal" trading range of securities. Stocks traded at a lower brokerage fee within the optimal range, were appealing to institutional and wealthy investors, and affordable for retail investors. Consequently, trading volume would increase. Corporate activity such as stock split was believed to be motivated by the optimal trading range hypothesis (Baker \& Gallagher, 1980; Baker, Phillips, \& Powell, 1995; Ikenberry et al., 1996, Lamourex \& Poon, 1987). After a stock split event, the larger number of available shares allowed investors to trade conveniently, which increased trading volume. Demsetz (1968) suggested that higher trading volume would reduce bid-ask spread, one of the commonly used measures of liquidity (Amihud \& Mendelson, 1986; Chordia, Roll, \& Subrahmanyam, 2000, 2001, 2002, 2008). In brief, ideally optimal trading range provided diversification benefits, better liquidity and lowered transaction cost (Conroy et al., 1990).

For STBL, Amihud et al. (1999) tested the effects of voluntary reductions in MTU in the Japanese equity market. The results showed an increase in the number of individual investors' post-MTU reduction. This was consistent with the view that firms which chose to reduce their MTU would increase their investor base. The research also documented positive cumulative abnormal returns after the announcement and implementation of the reduction in MTU. They also found that trading volume and illiquidity improved after the changes. Amihud et al. (1999) concluded that the significant increase in stock price and liquidity were driven by the increase in shareholders.

Isaka (2014) also sought evidence from the Japanese stock markets. He found that firms with low visibility had stronger motivation to reduce their MTU size. This led to a significant increase in individual shareholder base after the reduction. In addition, Ahn et al. (2014) found that the MTU reduction had asymmetry effects on firms. Even though stock prices post-MTU reduction was less noisy and more efficient, not every firm would opt to reduce their MTU. Firms with larger market capitalization and smaller number of shareholders were more likely to reduce MTU size. 
Hauser and Lauterbach (2003) examined the effect of MTU revision using a sample of firms from the Tel Aviv Stock Exchange between 1998 and 1999. On aggregate, when MTU increased, trading volume decreased and when MTU decreased, it led to an increase in trading volume, valuation, and return volatility. In a more recent study, Gozluklu et al. (2015) investigated the effect of reducing MTU in Borsa Italiana from multiple sizes to one unit. There was an improvement in market liquidity after the MTU reduction, indicated by a decrease in the bid-ask spread at the first five levels of the order book. In brief, MTU reduction led to an increase in uninformed traders, lower adverse selection costs and improvement in liquidity. Therefore, we put forward the following hypothesis:

$\mathrm{H}_{2}$ : Liquidity is significantly affected by STBL events.

\section{Methodology}

\subsection{Data and Variables}

This section is divided into two parts. The first part discusses the data and sample characteristics. The second part describes the variables and the measurements.

\subsubsection{Data and sample characteristics}

Our sample comprised firms affected by the standardization event in 2003 which were collected from four different dates: (1) $5^{\text {th }}$ February (Announcement date), (2) $7^{\text {th }}$ April (First stage of implementation), (3) $28^{\text {th }}$ April (Second stage of implementation), and (4) $26^{\text {th }}$ May (Third stage of implementation). The first announcement of the event was made by the then executive chairman of the KLSE, Datuk Mohd Azlan Hashim, on Friday, $31^{\text {st }}$ January 2003. On the announcement day, the market was closed and remained closed for five consecutive days starting from $31^{\text {st }}$ January (Friday) to $4^{\text {th }}$ February (Tuesday) due to a long weekend. The market resumed trading on $5^{\text {th }}$ February (Wednesday). ${ }^{2}$

The first announcement was made on a non-trading day, so $5^{\text {th }}$ February was assumed to be the event day (Day 0) which was the next-available trading day after the long weekend. There were 1,120 counters listed on the KLSE across all trading boards on that day, of which 871 were unique firms and 249 were derivative securities. The latter were excluded as the main focus of this study was on the main firms. Two firms from the main focus were also excluded due to insufficient data, resulting in 869 firms in the final sample. We also investigated the implementation effect of STBL on the market. The implementation dates were utilized as another set of events. This allowed us to compare market reaction surrounding the announcement day and implementation days. 
Table 1. Sample for STBL event

\begin{tabular}{llc}
\hline \multicolumn{1}{c}{ Event date (Day 0) } & \multicolumn{1}{c}{ Affected firm } & $\begin{array}{c}\text { Number of } \\
\text { firms }\end{array}$ \\
\hline $\begin{array}{l}5 \text { February 2003 } \\
\text { (Announcement day) }\end{array}$ & Firms listed on the KLSE & 869 \\
7 April 2003 & & 289 \\
$\begin{array}{l}\text { (First stage) } \\
\text { 28 April 2003 } \\
\text { (Second stage) }\end{array}$ & $\begin{array}{l}\text { Firms listed on the Trading/Services } \\
\text { sector of the Main Board }\end{array}$ & 106 \\
$\begin{array}{l}\text { 26 May 2003 } \\
\text { (Third stage) }\end{array}$ & Remaining firms (including MESDAQ) & 474 \\
\hline
\end{tabular}

Note. The figures stated in the table are based on the number of firms involved in the standardization event, which represents the main counter of a firm, and excludes any derivative securities.

The first stage of implementation affected 289 counters listed on the Second Board of the KLSE, while the second stage affected 106 Trading/ Services stocks listed on the Main Board. The third stage (final stage) of the implementation affected the remaining 474 firms on the KLSE. The chronology of the standardization event is summarized in Table 1.

\subsection{Variables}

This section discusses the dependent and independent variables used in this study.

\subsubsection{Dependent variable}

We used event study methodology to determine the market reaction surrounding the events of interest. The event days were labelled as Day 0, which were $5^{\text {th }}$ February (Announcement), $7^{\text {th }}$ April (First stage), $28^{\text {th }}$ April (Second stage), and $26^{\text {th }}$ May (Third stage). The estimation window of each event was set to be from Day -200 to Day -11 (-200, -11) from the event day. This estimation window was necessary to obtain a normal historical return that was free from the influence of preceding events. ${ }^{3}$

This study used market model to estimate normal return (MacKinlay, 1997). FTSE Bursa Malaysia EMAS Index (FBMEMAS), which comprised the FTSE Bursa Malaysia Top 100 Index (FBM100) and the FTSE Bursa Malaysia 
Small Cap Index (FBMSCAP), was selected as the market index. This was consistent with the nature of our event that affected all stocks listed on the KLSE. 4

In the market model, two parameters namely (intercept) and (slope) are obtained by regressing the daily return of firm $i$ with the market return (FBMEMAS) in the estimation period. Using these parameters, the abnormal return of firm $i$ on day $t$ is calculated as summarized in Equation (1).

$$
A R_{i, t}=R_{i, t}-\left(\hat{\alpha}_{i}+\hat{\beta}_{i} R_{m, t}\right)
$$

Where $R_{i, t}$ is the return of firm $i$ on day $t ; R_{m, t}$ is the return of market index on day $t$, and $\hat{\alpha}_{i}$ and $\hat{\beta}_{i}$ are the parameters estimated from the estimation period.

\subsubsection{Cross-sectional regressions}

Next, a cross-sectional regression analysis was performed to examine whether market reaction following the STBL event was driven by other firm-specific factors in addition to the announcement effect. Equation (2) shows the regression model used to examine market reaction surrounding the event days. Table 2 explains the variables and measurements used in this study.

$$
\begin{aligned}
\text { CAR }_{i, t_{1}, t_{2}=} & \beta_{0}+\beta_{1} \text { Spread }_{i}+\beta_{2} \text { Illquidity }_{i}+\beta_{3} \text { T_Activity }_{i}+\beta_{4} \text { Lot }_{-} 1000_{i}+ \\
& \beta_{5} \text { Size }_{i}+\beta_{6} \text { Volatility }_{i}+\beta_{7} T_{-} \text {Incentive }_{i}+\beta_{8} \text { Inv }_{-} O p_{i}+\varepsilon_{i}
\end{aligned}
$$

Table 2. Variables and measurements

\footnotetext{
$C A R_{i, t_{1}, t_{2}} \quad C A R_{i, t_{1}, t_{2}}$ is the cumulative abnormal return of firm $i$ surrounding the events from Day $t_{l}$ to Day $t_{2}$, where $A R_{t}$ is the daily abnormal return of firm $i$ on Day $t$.

$$
C A R_{i, t_{1}, t_{2}}=\sum_{t=t_{1}}^{t_{2}} A R_{i, t}
$$

Spread $_{i} \quad$ Bid-ask spread of firm $i$, measured by the average daily bid-ask spread from Day 200 to Day -11. Ask $\mathrm{A}_{i, t}$ and $\mathrm{Bid}_{i, t}$ is the ask price and bid price of firm $i$ on day $t$ respectively.

$$
\text { Bid }- \text { ask } \operatorname{spread}_{i, t}(\%)=\frac{A s k_{i, t}-\text { Bid }_{i, t}}{A s k_{i, t}}
$$

Illiquidity $_{i} \quad$ Illiquidity of firm $i$, measured by the average daily Amihud illiquidity ratio from Day -200 to Day -11. Volume turnover ${ }_{i, t}$ (in RM) is the volume turnover (in unit) of firm $i$ on day $t$, multiplied by the stock price on the same day.

$$
\text { Illiquidity }_{i, t}=\frac{\left|\ln \frac{P_{i, t}}{P_{i, t-1}}\right|}{\text { Volume turnover }{ }_{i, t} \text { (in RM) }} \times 10^{6}
$$
}




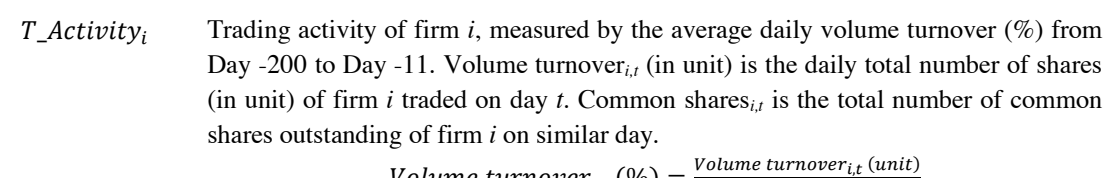

Lot_1000 $\quad$ Dummy variable for firm $i$ with original lot size of 1000 units per share prior to the standardization. Value of 1 is given to firms that meet the description and 0 for otherwise.

Size $_{i} \quad$ Size $_{i}$ of firm $i$, measured by the natural log of the average daily market capitalization of firm $i$ from Day -200 to Day -11. Market capitalization is calculated by multiplying the stock price of firm $i$ on day $t$ with its common shares outstanding of the same day.

$$
\text { Market value of } \text { equity }_{i, t}=\ln \left({\text { market } \left.\text { capitalization }_{i, t}\right)}\right.
$$

Volatility $_{i} \quad$ Volatility of firm $i$, measured by the standard deviation of daily return from Day 200 to Day -11 .

$T_{\_}$Incentive $e_{i} \quad$ Trading incentive of firm $i$, measured by the average daily relative tick size of firm $i$ from Day -200 to day -11 . Tick size $e_{i, t}$ is the nominal tick size, which is conditional to the stock price of firm $i$ on day $t^{5}$

$$
\text { Relative tick size } \text { sit, }_{(\%)}=\frac{\text { Tick size }_{i, t}}{P_{i, t}}
$$

Inv_Op $p_{i} \quad$ Investment opportunity of firm $i$, measured by the average daily book-to-market value from Day -200 to Day -11. Book value per share is $_{i, t}$ is the book value of equity per share of firm $i$ on day $t$.

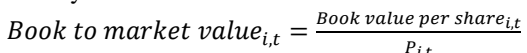

Note. $P_{i, t}$ is the closing price of stock $i$ on day $t$. Daily return of stock $i$ is calculated using $\ln \frac{P_{i, t}}{P_{i, t-1}}$. With the exception of Lot_1000, each independent variable is the average value of their respective measures estimated from Day -200 to Day -11 prior to announcement, intended to minimize the number of missing variables.

\section{Analysis of Results}

\subsection{Event Study Analysis}

This section discusses the effect of the standardization events on returns by analysing the average abnormal returns (AAR) and cumulative average abnormal returns (CAAR) surrounding the event days. To investigate the aggregate effect of the events on the market as a whole, all listed firms on the announcement date were included in the sample. The same sample was also used to gauge the implementation effect on aggregate market returns. A standardized pool of firms allowed us to compare the aggregate market reaction during the event days, and was not limited to affected firms at each stage of implementation. 
Table 3 presents the results of AAR from Day -10 to Day +10 surrounding the four event days. The AAR on Day 0 is found to be significantly negative on announcement day, with only 234 out of 808 (29\%) observations showing positive abnormal returns. On the contrary, during the first and third stage of implementation approximately $47 \%$ and $54 \%$ of firms reported positive abnormal returns, respectively. The AARs are statistically insignificant for the second stage.

Table 3 also reports the CAARs over various event windows that show market reaction surrounding the event days. Event window $[0,+1],[-10,-1]$, and $[+2,+10]$ are designed to determine the CAAR of the event, pre-event, and post-event period, respectively. On announcement day, the observed event windows show significant negative CAARs except $[+2,+10]$ which is positive but insignificant. The lowest CAAR recorded is $-4.977 \%$, observed from event window $[-5,+5]$. This value is smaller than the CAARs determined from event window $[-10,+10]$ and $[-10,-1]$, which suggest that the negative sentiments are more concentrated when closer to event day. This is evident by the line chart illustrated in Figure 1, showing a persistent negative trend starting from Day -6 to Day +3 . The CAAR from the window is $-6.854 \%$, significant at the $1 \%$ level.

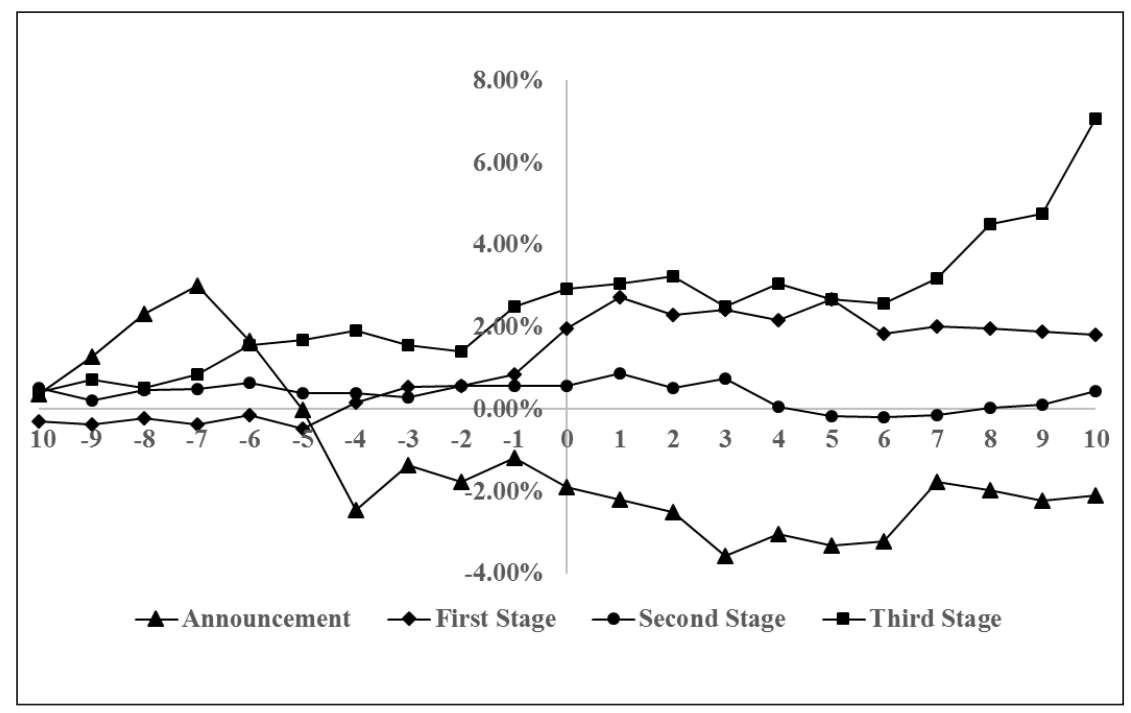

Figure 1. CAARs of Events from Day -10 to Day +10

As highlighted earlier, the announcement's event window coincided with Chinese New Year. Empirical studies on the Malaysian stock market have found that generally, positive market reactions prevailed during the immediate period 
before the Lunar Festival, resulting in significantly higher returns (Ho, 1990; Wong, Neoh, Lee, \& Thong, 1990; Yuan \& Gupta, 2014). On the contrary, we observed a significant negative market reaction surrounding a similar period. This can be explained by the heightened level of uncertainties in international markets when the potential for war in Iraq escalated (KLSE, 2003). Studies found that the Malaysian stock market tended to overreact to extraordinary political events, as well as to economic and financial crises, both internally and externally (Ali, Nassir, Hassan, \& Abidin, 2010; Tuyon \& Ahmad, 2016). The negative market sentiment seemed to be the greater concern for investors at that time, which nullified the supposedly positive festive-effect, and thus, explained the negative CAARs observed.

The first stage of implementation shows significant positive CAARs in almost various event windows. Event window $[-5,+5]$ indicates the highest return of $2.811 \%$, statistically significant at the $1 \%$ level. This positive reaction reflects investors' optimistic expectations of the new policy. The market is informed of the details related to the events (e.g. event date, affected firms) before the implementation takes place. Therefore investors could make strategic decisions prior to the first stage of implementation. This is because the market has been informed of the new policy on announcement day. Evidently, the CAAR for the event-day $[0,+1]$ shows a value of $1.879 \%$, which is higher than the return recorded in either the pre-event $[-10,-1]$ or post-event $[+2,+10]$ window, with a value of $0.849 \%$ and $-0.924 \%$, respectively.

None of the reported windows are found to be statistically significant for the second stage. Even though the 7 -day returns $[-3,+3]$ surrounding the event day is positive, the CAAR is marginal (CAAR $=0.356 \%$ ) and insignificant ( $p$-value $=0.6136$ ). The plausible explanation for the weak market reaction could be due to the type of affected firms. The affected firms are in the trading/services sector. In general, this sector constituted highly liquid firms. Therefore, the benefit of having a smaller trading lot size is less significant to this group of firms compared to other affected firms in the first and third stage of the implementation. This is supported by the higher market capitalization (size) and bid-ask spread (spread) reported in Panel C of Table 4.

The tested windows in the third stage show positive CAARs, significant at conventional levels, except event window $[-3,+3]$. Event window $[0,+1]$ reports the smallest CAAR of $0.558 \%$, while $[-10,+10]$ records the highest CAAR of $7.066 \%$. The CAAR for pre-event $[-10,-1]$ and post-event $[+2,+10]$ windows are $2.499 \%$ and $4.009 \%$, respectively. This suggested that even though the overall market reaction was positive around the final stage of implementation, the effect was stronger after the lot size reduction, indicating a positive market reception following the implementation of the new policy. 


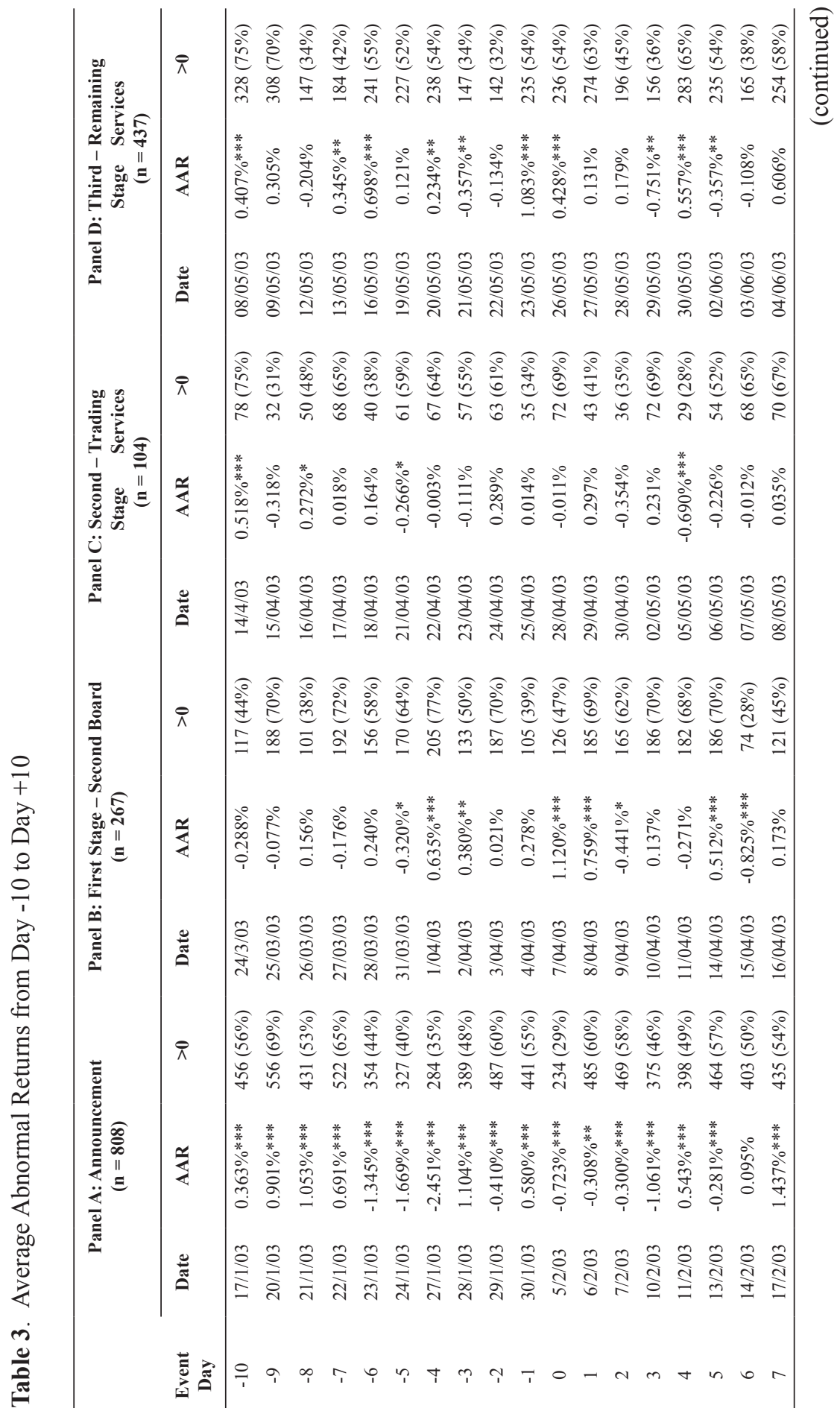




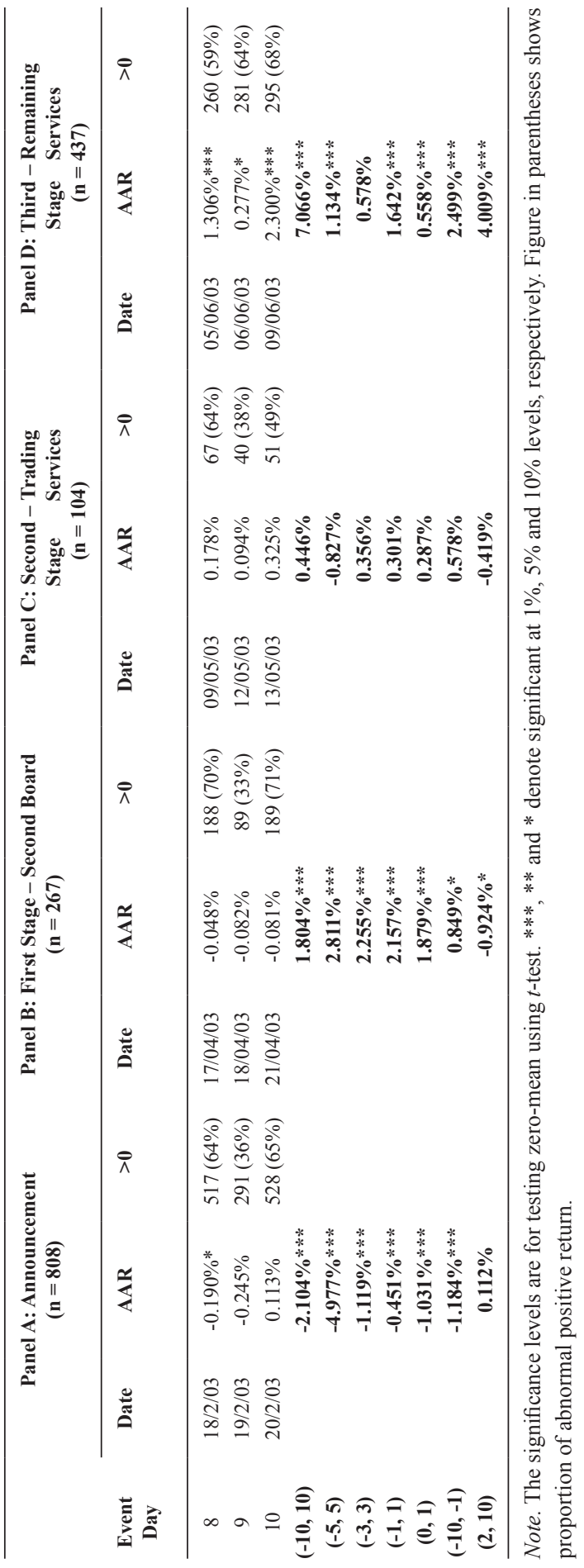




\subsection{Cross-Sectional Regression Analysis}

The time distance from one event to the next event was short. The gap was 41 days from the announcement of MTU reduction to the first stage of implementation; 15 days' gap between the first and second stage; and 17 days' gap between the second and final stage of implementation. To ensure that the identified independent variables were free from the influence of the preceding event, we utilized the average value of each independent variable from Day -200 to Day -11 prior to the announcement. This also minimized the problem of missed observations.

Table 4 summarizes the descriptive analysis of the identified variables. The data presented in the table have been treated for outliers by truncating extreme values identified using the 3 -sigma rule. The outliers had to be truncated, as they could distort the results of the study. The mean and median of CARs are consistently positive in the implementation stages, which signal positive market reception on the smaller lot size. As for the announcement effect, the CARs are negative ( mean $=-1.06 \%$ and median $=-0.05 \%$ ), indicating an aggregate downward trend across the market. As argued earlier, the negative abnormal returns may be driven by the negative market sentiment at that time, instead of the information content of the announcement.

Table 4 also shows that the affected firms in the first stage have a uniform lot size of 1,000 units. In comparison to the other stages, this group of firms are, on average, less liquid (14.93), smaller in size (RM65.04 million), and more volatile $(2.95 \%)$. These firms also have higher bid-ask spread $(5.34 \%)$, less trading incentive (13.58\%), and lower investment opportunities $(0.6 \times)$. The smaller size could also explain the higher trading activity (mean $=0.15 \%$; max. $=145 \%)$ shown by these firms.

The firms in the second stage are the most liquid, reporting the lowest bid-ask spread (2.19\%) and illiquidity ratio (1.28). The average volume turnover is $0.09 \%$, but this figure could be influenced by comparatively larger market capitalization. A huge difference is observed between the mean (RM1,194 million) and median (RM273.19 million) values, indicating it is strongly rightskewed, even after the outliers treatment. On average, the firms are less risky (volatility $=2.12 \%)$ and have the highest relative tick-size $(16.16 \%)$ and bookto-market value $(1.07 \times)$.

As for the third stage, the mean values of the following variables are higher than the first stage, but lower than the second stage - size, trading incentive, and investment opportunity. On the other hand, the values of spread, illiquidity, trading activity, and volatility, are lower than the first stage, but higher than the second stage. Overall, there is a distinct difference in the characteristics of firms affected in each stage; the first stage housed speculative stocks; the second stage hosted the blue-chips, and the third stage represented the rest of the markets, which are less extreme compared to firms from the first two stages. 
Table 4. Descriptive Statistics

\begin{tabular}{|c|c|c|c|c|c|c|}
\hline & $\mathbf{N}$ & Mean & Median & Minimum & Maximum & Std. dev. \\
\hline \multicolumn{7}{|c|}{ Panel A: Announcement } \\
\hline CAR (\%) & 802 & -1.06 & -0.05 & -14.50 & 12.56 & 3.37 \\
\hline Spread (\%) & 793 & 3.72 & 2.50 & 0.49 & 19.90 & 3.39 \\
\hline Illiquidity & 799 & 7.20 & 1.80 & 0.00 & 206.78 & 20.49 \\
\hline T. Activity (\%) & 781 & 0.11 & 0.05 & 0.00 & 1.45 & 0.19 \\
\hline Lot 1000 & 869 & 0.96 & 1 & 0 & 1 & 0.19 \\
\hline Size (RM million) & 814 & 368.07 & 112.73 & 1.07 & $5,900.19$ & 752.83 \\
\hline Volatility (\%) & 829 & 2.53 & 2.25 & 0.00 & 8.97 & 1.45 \\
\hline T. Incentive (\%) & 847 & 13.75 & 9.88 & 0.54 & 49.12 & 13.15 \\
\hline Inv. Opp. & 820 & 0.87 & 1.06 & -13.04 & 14.29 & 1.99 \\
\hline \multicolumn{7}{|c|}{ Panel B: First Stage - Second Board } \\
\hline CAR $(\%)$ & 264 & 1.63 & 0.30 & -13.90 & 17.67 & 4.68 \\
\hline Spread (\%) & 260 & 5.34 & 3.88 & 0.78 & 23.46 & 4.23 \\
\hline Illiquidity & 264 & 14.93 & 4.45 & 0.02 & 354.94 & 39.91 \\
\hline T. Activity (\%) & 254 & 0.15 & 0.06 & 0.00 & 1.45 & 0.24 \\
\hline Lot 1000 & 289 & 1.00 & 1 & 1 & 1 & 0.00 \\
\hline Size (RM million) & 270 & 65.04 & 51.78 & 1.07 & 712.61 & 68.68 \\
\hline Volatility $(\%)$ & 275 & 2.95 & 2.66 & 0.00 & 8.95 & 1.55 \\
\hline T. Incentive (\%) & 282 & 13.58 & 8.00 & 0.58 & 44.54 & 13.35 \\
\hline Inv. Opp. & 270 & 0.60 & 1.05 & -18.88 & 14.29 & 2.69 \\
\hline \multicolumn{7}{|c|}{ Panel C: Second Stage - Trading/Services } \\
\hline CAR $(\%)$ & 101 & 0.50 & 0.17 & -8.68 & 8.57 & 2.32 \\
\hline Spread (\%) & 102 & 2.18 & 1.69 & 0.49 & 7.64 & 1.57 \\
\hline Illiquidity & 101 & 1.28 & 0.45 & 0.00 & 13.07 & 2.07 \\
\hline T. Activity (\%) & 100 & 0.09 & 0.05 & 0.00 & 0.49 & 0.11 \\
\hline Lot 1000 & 106 & 0.99 & 1 & 0 & 1 & 0.10 \\
\hline Size (RM million) & 102 & $1,194.63$ & 273.19 & 26.10 & $13,643.11$ & $2,629.46$ \\
\hline Volatility $(\%)$ & 104 & 2.12 & 2.03 & 0.00 & 4.16 & 0.90 \\
\hline T. Incentive (\%) & 106 & 16.16 & 14.31 & 0.61 & 44.19 & 13.51 \\
\hline Inv. Opp. & 103 & 1.07 & 0.92 & -0.06 & 2.86 & 0.66 \\
\hline \multicolumn{7}{|c|}{ Panel D: Third Stage - Remaining firms } \\
\hline CAR $(\%)$ & 420 & 0.71 & 0.35 & -9.19 & 10.65 & 2.89 \\
\hline Spread (\%) & 416 & 2.98 & 2.09 & 0.54 & 13.88 & 2.59 \\
\hline Illiquidity & 420 & 4.03 & 1.11 & 0.00 & 103.96 & 9.61 \\
\hline T. Activity $(\%)$ & 413 & 0.08 & 0.03 & 0.00 & 1.44 & 0.15 \\
\hline Lot 1000 & 459 & 0.97 & 1 & 0 & 1 & 0.18 \\
\hline Size (RM million) & 430 & 489.27 & 189.74 & 8.13 & $5,900.19$ & 863.15 \\
\hline Volatility $(\%)$ & 438 & 2.35 & 2.03 & 0.00 & 9.23 & 1.48 \\
\hline T. Incentive (\%) & 447 & 13.59 & 10.73 & 0.54 & 49.12 & 12.97 \\
\hline Inv. Opp. & 434 & 0.98 & 1.12 & -10.78 & 6.92 & 1.82 \\
\hline
\end{tabular}

Note. The values tabulated have been treated for outliers by truncating extreme values that are greater or less than the limits set using the 3-sigma rule. 
Table 5 presents the results of cross-sectional regression analysis of each event - announcement (Model 1), first stage (Model 2), second stage (Model 3), and third stage (Model 4). The study chose CAR $[0,+1]$ as the dependent variable in all the four models to examine the immediate effects following the STBL announcement and implementation. Three liquidity measures were identified as the independent variables: (1) bid-ask spread (2) Amihud illiquidity, and (3) trading activity. The regression model also controlled for other explanatory variables like original lot size, market capitalization, volatility, trading incentive, and investment opportunity.

Based on Table 5 and as reported earlier in Tables 3 and 4, market sentiment surrounding the announcement is negative. The reported CAARs are significantly negative. The result shows that six out of eight variables in Model 1 are statistically significant. The results suggest that during a period of high level uncertainty, investors require greater compensation to invest in firms of larger size, with bigger spread, higher illiquidity, lower volatility, smaller trading incentive, and lower investment opportunity.

Table 5. Regression Results

\begin{tabular}{|c|c|c|c|c|}
\hline Variable & $\begin{array}{l}\text { Announcement } \\
\text { Model } 1 \\
\mathbf{N}=742\end{array}$ & $\begin{array}{c}\text { First Stage } \\
\text { Model } 2 \\
\mathbf{N}=\mathbf{2 4 2}\end{array}$ & $\begin{array}{l}\text { Second Stage } \\
\text { Model } 3 \\
\mathrm{~N}=91\end{array}$ & $\begin{array}{c}\text { Third Stage } \\
\text { Model } 4 \\
\mathbf{N}=\mathbf{3 8 8}\end{array}$ \\
\hline Constant & $\begin{array}{l}-0.0256 \\
(0.2376)\end{array}$ & $\begin{array}{c}0.1659 \\
\left(0.0926^{*}\right)\end{array}$ & $\begin{array}{l}-0.0668 \\
(0.2187)\end{array}$ & $\begin{array}{c}0.0367 \\
(0.2014)\end{array}$ \\
\hline Spread & $\begin{array}{c}0.1589 \\
(0.0022 * * *)\end{array}$ & $\begin{array}{l}-0.1460 \\
(0.2082)\end{array}$ & $\begin{array}{c}-0.6928 \\
(0.0347 * *)\end{array}$ & $\begin{array}{c}0.0064 \\
(0.9467)\end{array}$ \\
\hline Illiquidity & $\begin{array}{c}0.0004 \\
\left(0.0215^{* *}\right)\end{array}$ & $\begin{array}{l}-0.0002 \\
(0.3549)\end{array}$ & $\begin{array}{c}0.0076 \\
(0.0353 * *)\end{array}$ & $\begin{array}{c}0.0003 \\
(0.2567)\end{array}$ \\
\hline T. Activity & $\begin{array}{l}-0.0519 \\
(0.9408)\end{array}$ & $\begin{array}{c}0.5582 \\
(0.7099)\end{array}$ & $\begin{array}{c}6.6356 \\
\left(0.0319^{* *}\right)\end{array}$ & $\begin{array}{l}-0.7131 \\
(0.6249)\end{array}$ \\
\hline Lot 1000 & $\begin{array}{l}-0.0037 \\
(0.5620)\end{array}$ & - & $\begin{array}{l}-0.0072 \\
(0.2679)\end{array}$ & $\begin{array}{c}0.0004 \\
(0.9676)\end{array}$ \\
\hline Size & $\begin{array}{c}0.0021 \\
\left(0.0498^{* *}\right)\end{array}$ & $\begin{array}{l}-0.0090 \\
(0.0912 *)\end{array}$ & $\begin{array}{c}0.0043 \\
(0.0584 *)\end{array}$ & $\begin{array}{l}-0.0011 \\
(0.4020)\end{array}$ \\
\hline Volatility & $\begin{array}{c}-1.1365 \\
\left(0.0000^{* * *}\right)\end{array}$ & $\begin{array}{c}0.4078 \\
(0.3006)\end{array}$ & $\begin{array}{l}-0.5093 \\
(0.2549)\end{array}$ & $\begin{array}{c}-0.3377 \\
\left(0.0213^{* *}\right)\end{array}$ \\
\hline T. Incentive & $\left(0.0154^{0.0203}\right)$ & $\begin{array}{l}0.0366 \\
(0.1160)\end{array}$ & $\begin{array}{l}-0.0094 \\
(0.5717)\end{array}$ & $(0.0081)$ \\
\hline Inv. Op. & $\left(0.0268^{-0.3 *}\right)$ & $\begin{array}{l}0.0021 \\
(0.1279)\end{array}$ & $\begin{array}{l}0.0043 \\
(0.4222)\end{array}$ & $\begin{array}{l}-0.0014 \\
(0.1718)\end{array}$ \\
\hline $\begin{array}{l}\text { Adj. R-squared } \\
\text { F-Statistics }\end{array}$ & $\begin{array}{l}16.52 \% \\
11.9536\end{array}$ & $\begin{array}{l}1.44 \% \\
1.7873\end{array}$ & $\begin{array}{l}12.79 \% \\
17.1785\end{array}$ & $\begin{array}{l}0.11 \% \\
1.1104\end{array}$ \\
\hline
\end{tabular}

Note. The significance levels are for testing a zero-mean using p-value. $* * *, * *$ and $*$ denote significant at $1 \%, 5 \%$ and $10 \%$ levels, respectively. Numbers in parentheses refer to $\mathrm{p}$-value. 
Model 2 shows that size has a significant negative effect on stock returns, suggesting that firms with smaller market capitalization enjoy greater abnormal returns following lot size reduction. The results are not significant for the other variables. This is potentially due to the sample firms. Model 2 only includes firms listed on the Second Board of the KLSE, which are generally smaller in size and investors are less informed about these firms compared to firms listed on the Main Board.

On the contrary, firms included in Model 3 are on average larger and more liquid compared to the rest of the firms in the market (see Table 4). This also means that there is more information available in the market about these firms, thus reducing the information asymmetric problem. Model 3 shows that four out of the eight independent variables are statistically significant. The results suggest that after the second stage of implementation, stocks with smaller spread, higher illiquidity, greater trading activity, and larger market capitalization experience greater abnormal returns.

Model 4 presents the regression analysis of the final stage of implementation. Volatility is found to be statistically significant at the $5 \%$ level. The negative coefficient suggests that firms with a lower level of volatility experience greater abnormal returns after the lot size reduction. Other control variables have insignificant effects on returns.

In comparison, we find that the selected variables are able to explain $16.52 \%$ (Model 1) and 12.79\% (Model 3) of the variation in CAR. However, the same sets of variables are less useful in explaining the CAR, evidenced by the low adjusted R-squared value of 1.44\% (Model 2) and 0.11\% (Model 4). The findings suggest that market reactions observed during these two stages are mostly driven by the implementation effect of the event. Therefore, the influence of firm-specific factors such as liquidity, trading incentive and investment opportunities on returns are insignificant.

\subsection{Liquidity Pre- and Post STBL Implementation}

Our study used univariate tests to examine stocks liquidity before and after the STBL implementation. The liquidity was measured by bid-ask spread, Amihud illiquidity, and volume turnover. Table 5 presents the results of paired sample t-test which are grouped based on their implementation stages - Panel A (first stage), Panel B (second stage), and Panel C (third stage). On the other hand, Panel D represents the combined sample of all firms affected by the standardization event.

The mean difference test shows that spread improved significantly following the standardization event in each stage of implementation. The significant improvement is seen in the first stage, where the bid-ask spread decreases by $1.91 \%$. The smaller spread post-implementation indicates a narrower 
level of information asymmetry in the market, and thus, an improvement in the liquidity. The spread for the second and third stage is reduced by $0.57 \%$ and $1.23 \%$, respectively. Trading activity also improves significantly across the stages. Volume turnover increases consistently, by $0.4 \%$ in the first stage, $0.12 \%$ in the second stage, and $0.15 \%$ in the final stage. The higher post-STBL values suggest greater market activity following the microstructure change. This result is consistent with previous studies that reported higher participation in the market after MTU reduction (e.g. Amihud et al., 1999; Gozluklu et al., 2015).

Table 6. Paired Sample t-test

\begin{tabular}{|c|c|c|c|}
\hline & Spread & Illiquidity & T. Activity \\
\hline \multicolumn{4}{|c|}{ Panel A: First Stage - Second Board } \\
\hline Pre & 0.0591 & 21.1776 & 0.0020 \\
\hline Post & 0.0400 & 23.5716 & 0.0060 \\
\hline Diff & $-0.0191 * * *$ & 2.3940 & $0.0040 * * *$ \\
\hline P-value & 0.0000 & 0.7708 & 0.0000 \\
\hline $\mathrm{N}$ & 255 & 255 & 251 \\
\hline \multicolumn{4}{|c|}{ Panel B: Second Stage - Trading/Services } \\
\hline Pre & 0.0246 & 2.3570 & 0.0009 \\
\hline Post & 0.0189 & 1.2657 & 0.0021 \\
\hline Diff & $-0.0057 * * *$ & $-1.0913 * * *$ & $0.0012 * * *$ \\
\hline P-value & 0.0000 & 0.0042 & 0.0000 \\
\hline $\mathrm{N}$ & 104 & 104 & 100 \\
\hline \multicolumn{4}{|c|}{ Panel C: Third Stage - Remaining firms } \\
\hline Pre & 0.0355 & 10.8265 & 0.0009 \\
\hline Post & 0.0232 & 4.9184 & 0.0024 \\
\hline Diff & $-0.0123 * * *$ & $-5.9081 *$ & $0.0015 * * *$ \\
\hline P-value & 0.0000 & 0.0755 & 0.0000 \\
\hline $\mathrm{N}$ & 419 & 419 & 410 \\
\hline \multicolumn{4}{|c|}{ Panel D: Combined } \\
\hline Pre & 0.0418 & 13.0871 & 0.0013 \\
\hline Post & 0.0281 & 10.5440 & 0.0035 \\
\hline Diff & $-0.0136^{* * *}$ & -2.5431 & $0.0023 * * *$ \\
\hline P-value & 0.0000 & 0.4311 & 0.0000 \\
\hline $\mathrm{N}$ & 778 & 778 & 761 \\
\hline
\end{tabular}

Note. Pre $=$ Average value of respective variable from Day -250 to Day -1 . Post $=$ Average value of respective variable from Day 0 to Day +250 . Diff $=$ Post - Pre. The significance levels are for testing zero-mean using p-value. $* * *, * *$ and $*$ denote significant at $1 \%, 5 \%$ and $10 \%$ levels, respectively. 
On the other hand, we found inconsistent results regarding the implementation effect of STBL on illiquidity. The results showed that while the Amihud illiquidity ratio of the affected firms in the second and third stage were significantly lower in the post-event period, the result was insignificant in the first stage of implementation. This indicated that the liquidity effect of having smaller lot size was not uniform across the affected firms. Our findings concurred with the results reported by Ahn et al. (2014), Isaka (2014) and Isaka and Yoshikawa (2013). Their findings suggested that MTU reduction was unable to reduce the illiquidity problem faced by firms that were less liquid, smaller in size, more volatile, and had less investment opportunities.

Panel D presents the liquidity performance of all affected firms. The results show that on average, firms experience lower spread $(-1.36 \%)$ and higher trading activity $(+0.23 \%)$ after the new policy was introduced, both significant at $1 \%$ level. Despite the improvements, the smaller lot size is found to be ineffective in mitigating illiquidity problem, as shown in the combined sample. For all the four stages, it could be argued that at least the illiquidity ratio did not deteriorate following STBL while bid-ask spread and trading activities improved, therefore STBL as a whole improved the liquidity of stocks in Malaysia.

\section{Conclusion}

This study examined the effects of STBL on stock returns and liquidity in Malaysian listed firms, which was announced and implemented in 2003. This study has contributed to the literature on minimum trading unit (MTU) or board lot size by testing and providing evidence on various theories using data from the Malaysian stock market. Although STBL in theory should have no real effect on firm value, the study found that investors reacted negatively to the announcement, yet positively following its implementation. The negative abnormal returns observed during the announcement were believed to be driven by the negative market sentiment at that time.

On the contrary, the study found significant positive reaction during the implementation period, which indicated positive market reception of the new lot size. The regression analyses showed that the market reaction observed during the first and the third stage of implementation were mainly driven by the implementation effect of the event, and thus, disregarded firm-specific factors such as liquidity, trading incentive, or investment opportunity. As for the second stage, the event study found that there was insignificant market reaction during the implementation day because the STBL event only affected a specific group of firms in the trading/services sector, causing the results to be different from the other two stages. 
The univariate tests showed inconsistent results on the implementation effect of STBL on illiquidity. The results showed that the effect of STBL was not uniform across firms, and the policy neither improved nor deteriorated illiquidity of firms listed on the Second Board. However, in all stages, there were improvements in the bid-ask spread and trading activities, which proved that STBL as a whole was able to improve liquidity of stocks in Malaysia. Future studies should attempt to compare market reaction following bonus issues and stock split events in Malaysia during the pre- and post-STBL period, since they are fundamentally similar.

\section{End Notes}

1 MESDAQ was launched on 6th October 1997 as a separate securities market in the KLSE for high-tech or growth firms. MESDAQ is currently known as ACE Market, effective 3rd August 2009.

2 The market was closed one day in advance of Federal Territory Day (Hari Wilayah Persekutuan) on 1st February, and Chinese New Year fell on 1st and 2nd February (Saturday and Sunday). Since the public holidays (Chinese New Year) fell on a Saturday which is a holiday (Hari Wilayah Persekutuan) and a Sunday, the following Monday and Tuesday (3rd and 4th February) were declared replacement holidays. This is a common practice in Malaysia.

3 An estimation window that is near to the event day will be influenced by information from the preceding events especially during the final stage of implementation, and therefore this will affect the estimation of normal returns.

4 FBM100 comprises 100 largest firms by full market capitalization, while the FBMSCAP comprises firms within the top $98 \%$ of the Main Market by full market capitalization, but are not constituents of FBM100. The FTSE Bursa Malaysia KLCI Index (FBMKLCI) is not chosen as the market benchmark because the index includes only 30-largest firms by market capitalization.

5 The nominal tick sizes applied in this study are as follows:

\begin{tabular}{cc}
\hline Price range & Tick size (Sen) \\
\hline Below RM1.00 & 0.5 \\
RM1.00 to RM2.99 & 1 \\
RM3.00 to RM4.98 & 2 \\
RM5.00 to RM9.95 & 5 \\
RM10.00 to RM24.90 & 10 \\
RM25.00 to RM99.75 & 25 \\
RM100.00 and above & 50 \\
\hline
\end{tabular}




\section{References}

Acharya, V. V., \& Pedersen, L. H. (2005). Asset pricing with liquidity risk. Journal of Financial Economics, 77, 375-410.

Ahn, H. (2014). Does trading by small investors improve or deteriorate price efficiency? Evidence from the minimum trade unit changes on the Korea Exchange. International Journal of Financial Studies, 2(2), 203-219.

Ahn, H., Cai, J., Hamao, Y., \& Melvin, M. (2014). Little guys, liquidity, and the informational efficiency of price: Evidence from the Tokyo Stock Exchange on the effects of small investor participation. Pacific-Basin Finance Journal, 29, 163-181.

Akerlof, G. A. (1970). The market for "lemons": Quality uncertainty and the market mechanism. The Quarterly Journal of Economics, 84(3), 488500.

Ali, N., Nassir, A. M., Hassan, T., \& Abidin, S. Z. (2010). Short run stock overreaction: Evidence from Bursa Malaysia. International Journal of Economics and Management, 4(2), 319-333.

Amihud, Y. (2002). Illiquidity and stock returns: Cross-section and time-series effects. Journal of Financial Markets, 5, 31-56.

Amihud, Y., \& Mendelson, H. (1986). Asset pricing and the bid-ask spread. Journal of Financial Economics, 17, 223-249.

Amihud, Y., Mendelson, H., \& Uno, J. (1999). Number of shareholders and stock prices: Evidence from Japan. Journal of Finance, 54, 1169-84.

Aydogan, K., \& Muradoglu, G. (1998). Do markets learn from experience? Price reaction to stock dividends in the Turkish market. Applied Financial Economics, 8(1), 41-49.

Baker, H. K., \& Gallagher, P. L. (1980). Management's view of stock splits. Financial Management, 9(2), 73-77.

Baker, H. K., Philips, A. L., \& Powell, G. E. (1995). The stock distribution puzzle: A synthesis of the literature on stock splits and stock dividends. Financial Practice and Education, (Spring/Summer), 24-37.

Barber, B. M., \& Odean, T. (2008). All that glitters: The effect of attention and news on the buying behavior of individual and institutional investors. The Review of Financial Studies, 21(2), 785-818.

Bechmann, K. L., \& Raaballe, J. (2007). The differences between stock splits and stock dividends: Evidence on the retained earnings hypothesis. Journal of Business Finance and Accounting, 34, 574-604.

Brennan, M. J., \& Copeland, T. E. (1988). Stock splits, stock prices, and transaction costs. Journal of Financial Economics, 22, 83-101.

Brennan, M., \& Hughes, P. (1991). Stock prices and the supply of information. The Journal of Finance, 46(5), 1665-1691. 
Chordia, T., Roll, R., \& Subrahmanyam, A. (2000). Commonality in liquidity. Journal of Financial Economics, 56(1), 3-28.

Chordia, T., Roll, R., \& Subrahmanyam, A. (2001). Market liquidity and trading activity. The Journal of Finance, 56(2), 501-530.

Chordia, T., Roll, R., \& Subrahmanyam, A. (2002). Order imbalance, liquidity, and market returns. Journal of Financial Economics, 65(1), 111-130.

Chordia, T., Roll, R., \& Subrahmanyam, A. (2008). Liquidity and market efficiency. Journal of Financial Economics, 87(2), 249-268.

Conroy, R. M., Harris, R. S., \& Benet, B. A. (1990). The effects of stock splits on bid-ask spreads. Journal of Finance, 45(4), 1285-1295.

Copeland, T. E. (1979). Liquidity changes following stock splits. Journal of Finance, 34(1), 115-141.

Demsetz, H. (1968). The cost of transacting. Quarterly Journal of Economics, 82(1), 33-53.

Desai, H., \& Jain, P. C. (1997). Long-run common stock returns following stock splits and reverse splits. The Journal of Business, 70(3), 409-433.

Elfakhani, S., \& Lung, L. (2003). The effect of split announcements on Canadian stocks. Global Finance Journal, 14, 197-216.

Eng, L. L., Ha, J., \& Nabar, S. (2014). The impact of regulation FD on the information environment: Evidence from the stock market response to stock split announcements. Review of Quantitative Finance and Accounting, 43(4), 829-853.

Fama, E. F., Fisher, L., Jensen, M. C., \& Roll, R. (1969). The adjustment of stock prices to new information. International Economics Review, 10(1), $1-21$.

Gozluklu, A. E., Perotti, P., Rindi, B., \& Fredella, R. (2015). Lot size constraints and market quality: Evidence from the Borsa Italiana. Financial Management, 44(4), 905-945.

Gray, S. F., Smith, T., \& Whaley, R. E. (2003). Stock splits: Implications for investor trading costs. Journal of Empirical Finance, 10(3), 271-303.

Grinblatt, S. M., Masulis, R. W., \& Titman, S. (1984). The valuation effects of stock splits and stock dividends. Journal of Financial Economics, 13, 97-112.

Hauser, S., \& Lauterbach, B. (2003). The impact of minimum trading units on stock value and price volatility. Journal of Financial and Quantitative Analysis, 38, 575-589.

Ho, Y. K. (1990). Stock return seasonalities in Asia Pacific Market. Financial Management and Accounting, 2, 47-77.

Huang, G. C., Liano, K., \& Pan, M. S. (2006). Do stock splits signal future profitability? Review of Quantitative Finance and Accounting 26, 347367.

Ikenberry, D. L., Rankine, G., \& Stice, E. K. (1996). What do stock splits really 
signal? Journal of Financial and Quantitative Analysis, 31(3), 357-375. Isaka, N. (2014). Long-run effects of minimum trading unit reductions on stock prices. International Review of Finance, 14(1), 75-103.

Isaka, N., \& Yoshikawa, H. (2013). Stock price reactions following minimum trading unit reductions and stock splits: Evidence from Japan. Financial Decisions, 25(2), 1-19.

Kuala Lumpur Stock Exchange Berhad. (2003). Annual report 2003. Retrieved from http://bursa.listedcompany.com/misc/ar2003.pdf

Lamoureux, C. G., \& Poon, P. (1987). The market reaction to stock splits. Journal of Finance, 42(5), 1347-1370.

Lyroudi, K., Dasilas, A., \& Varnas, A. (2006). The valuation effects of stock splits in NASDAQ. Managerial Finance, 32(5), 401-414.

MacKinlay, A. C. (1997). Event studies in economics and finance. Journal of Economic Literature, 37, 13-39.

Malaysia bourse plans to cut share trading lot. (2003, January 31). Reuters News. Retrieved from https://global.factiva.com

McNichols, M., \& Dravid, A. (1990). Stock dividends, stock splits, and signalling. Journal of Finance, 45(3), 857-879.

Mukherji, S., Kim , Y. H., \& Walker, M. C. (1997). The effect of stock splits on the ownership structure of firms. Journal of Corporate Finance, 3(2), 167-188.

Nayak, S., \& Prabhala, N. R. (2001). Disentangling the dividend information in splits: A decomposition using conditional event-study methods. Review of Financial Studies, 14(4), 1083-1116.

O’Hara, M. (1995). Market Microstructure Theory. Oxford: Blackwell Publishing Limited.

Pavabutr, P., \& Sirodom, K. (2010). Stock splits in a retail dominant order driven market. Pacific-Basin Finance Journal, 18(5), 427-441.

Securities Commission. (2001). Capital market masterplan Malaysia. Kuala Lumpur: Perpustakaan Negara Malaysia.

Sundaresan, S., \& Wang, Z. (2009). Y2K options and the liquidity premium in treasury markets. The Reviews of Financial Studies, 22(3), 1021-1056.

Tuyon, J., \& Ahmad, Z. (2016). Behavioural finance perspectives on Malaysian stock market efficiency. Borsa Istanbul Review, 16(1), 43-61.

Vernimmen, P., Quiry, P., Dallochio, M., Fur, Y. L., \& Salvi, A. (2009). Corporate finance: Theory and practice ( $2^{\text {nd }}$ ed.). West Sussex: John Wiley \& Sons Ltd.

Wong, P.L., Neoh, S.K., Lee, H.K., \& Thong, S.T. (1990) Seasonality in the Malaysian stock market. Asia Pacific Journal of Management, 7 (Special issue), 43-62.

Woolridge, J. R. (1983). Ex-date stock price adjustment to stock dividends: A note. Journal of Finance, 38(1), 247-255.

Yuan, T., \& Gupta, R. (2014). Chinese Lunar New Year effect in Asian stock 